\title{
Effects of the Excitatory Amino Acid Receptor Antagonists Kynurenate and Indole-2-Carboxylic Acid on Behavioral and Neurochemical Outcome following Experimental Brain Injury
}

\author{
Douglas H. Smith, ${ }^{1}$ Koichi Okiyama, ${ }^{1}$ Mark J. Thomas, ${ }^{2}$ and Tracy K. Mclntosh' \\ 'Division of Neurosurgery, University of Pennsylvania, Philadelphia, Pennsylvania 19104 and 'School of Medicine, \\ University of Connecticut Health Center, Farmington, Connecticut 06050
}

\begin{abstract}
The overactivation of the NMDA receptor is thought to be a major contributor to the pathophysiologic sequelae of traumatic brain injury (TBI), which commonly includes memory dysfunction. Uniquely, potentiation of the NMDA receptor is dependent on the binding of glycine to a distinct site on the receptor. Despite the potential role of the NMDA receptor in the development of post-TBI cognitive deficits, no studies to date have evaluated the efficacy of NMDA receptor antagonists on memory dysfunction after brain injury. Moreover, glycine site antagonists have not been employed as potential therapeutic agents in models of TBI. In the present study, we evaluated the effects of two glycine site antagonists, kynurenate (KYNA) and indole-2-carboxylic acid (I2CA), on memory and motor dysfunction, cerebral edema formation, and changes in regional total tissue brain $[\mathrm{Na}],[\mathrm{K}],[\mathrm{Ca}]$, $[\mathrm{Mg}]$, and [Zn], following lateral fluid-percussion brain injury in the rat. We found that both KYNA (300 mg/ $\mathrm{kg})$ and I2CA $(50 \mathrm{mg} / \mathrm{kg}$ and $20 \mathrm{mg} / \mathrm{kg}$ ) administered $15 \mathrm{~min}$ postinjury dramatically attenuated trauma-induced cognitive dysfunction $(p<0.01)$. In addition, both compounds improved neurologic motor deficits measured at 2 weeks following injury $(p<0.05)$. KYNA $(300 \mathrm{mg} / \mathrm{kg})$ reduced edema in the cortex, hippocampus, and thalamus, while $12 \mathrm{CA}(20 \mathrm{mg} / \mathrm{kg})$ reduced edema formation only in the thalamus. Differential effects of KYNA and I2CA on cation concentrations were also noted. KYNA attenuated the postinjury increase in regional tissue [Ca]; however, it had little effect on other cation concentrations. 12CA reversed the postinjury regional increases in [Na] and decreases in [K], [Mg], and [ $\mathrm{Zn}]$, but had little effect on [Ca] changes. These results indicate that KYNA and I2CA may have differential, but beneficial effects on both behavioral and neurochemical sequelae of TBI.
\end{abstract}

[Key words: brain injury, glycine antagonists, memory dysfunction, neurologic dysfunction, cerebral edema, cation homeostasis]

\footnotetext{
Received Nov. 11, 1992; revised June 3, 1993; accepted June 23, 1993.

This study was supported, in part, by a U.S. Public Health Service grant from the National Institute of Health (RO1-NS26818), a Veterans Administration Merit Review Grant (74R), and the Brain Trauma Foundation. We gratefully acknowledge David Serwanski and James Moore for their excellent technical assistance. In these studies, we carefully adhered to the animal welfare guidelines set forth in the Guide for the Care and Use of Laboratory Animals, U.S. Department of Health and Human Services, Publication 85-23, 1985.

Correspondence should be addressed to Douglas H. Smith, M.D., University of Pennsylvania, Division of Neurosurgery, 105 Hayden Hall, 240 South 33rd Street, Philadelphia, PA 19104.

Copyright (c) 1993 Society for Neuroscience $0270-6474 / 93 / 135383-10 \$ 05.00 / 0$
}

The NMDA receptor [an excitatory amino acid (EAA) receptor subtype] has been well characterized as part of a unique receptor-cation channel complex (MacDermott et al., 1986; Reynolds and Miller, 1988). Activation of this receptor includes obligatory binding of an EAA to the NMDA binding site and glycine to a strychnine-insensitive high-affinity glycine-binding site on the NMDA receptor (Kleckner and Dingledine, 1988). Although the NMDA receptor-associated ionophore is opened upon activation, a voltage-dependent block by magnesium $\left(\left[\mathrm{Mg}^{2+}\right]\right)$ must be overcome in order to allow an influx of calcium $\left(\left[\mathrm{Ca}^{2+}\right]\right)$ and sodium $\left(\left[\mathrm{Na}^{+}\right]\right)$into and efflux of potassium $\left(\left[\mathrm{K}^{+}\right]\right)$ from the neuron. In addition, the zinc ion ([ $\left.\left.\mathrm{Zn}^{2+}\right]\right)$ may bind to a distinct site, antagonizing NMDA receptor activation, possibly by noncompetitive antagonism of the glycine site (Yeh et al., 1990). The necessity of multiple regulatory sites on this receptor may be partially related both to its integral role in synaptic plasticity (Harris et al., 1984; Collingridge and Bliss, 1987) and to its susceptibility to pathologic overexcitation (Choi et al., 1987).

The pathophysiologic sequelae following traumatic brain injury (TBI) are believed to be mediated by secondary or delayed mechanisms, including an excessive release of EAAs with subsequent overactivation of the EAA receptors (Choi, 1988). Using intracerebral microdialysis techniques, a dramatic increase in extracellular EAA (glutamate and aspartate) concentrations has been reported following experimentally induced TBI (Faden et al., 1989; Katayama et al., 1990; Nilsson et al., 1990). It has also been shown that NMDA receptor antagonists may be beneficial in a variety of experimental brain injury models (Hayes et al., 1988; Jenkins et al., 1988; Faden et al., 1989; McIntosh et al., 1989a, 1990; Shapira et al., 1991), suggesting that pharmacologic antagonism of this receptor may attenuate excitotoxic-induced pathophysiologic aspects of TBI.

The NMDA receptor has also been shown to play a major role in memory function. NMDA receptor antagonists suppress long-term potentiation (LTP) (which has been described as the synaptic analog of memory), and impair cognitive function (Morris, 1989). Following experimental brain injury, suppression of LTP (Miyzaki et al., 1989) and profound learning and memory dysfunction (Lyeth et al., 1990; Smith et al., 1991; Hamm et al., 1992) have been demonstrated. In addition, a selective vulnerability of populations of neurons rich with NMDA receptors, including hippocampal neurons, has also been observed following experimental brain injury (Cortez et al., 1989; Kotapka et al., 1991; Lowenstein et al., 1992). In turn, hippocampal damage is thought to be a prerequisite for memory impairment (Scoville and Milner, 1957). Although disturbances 
in memory function are some of the most common features of human TBI (Levin, 1985), no studies to date have evaluated the effects of NMDA receptor antagonists on cognitive dysfunction following brain injury.

Kynurenate (KYNA) and indole-2-carboxylic acid (I2CA) and their halogenated derivatives, 7-chloro-KYNA and 5-fluoroI2CA, have been shown to be potent glycinc site antagonists, inhibiting NMDA receptor action via an allosteric (noncompetitive) mechanism (Kemp et al., 1988; Hüettner, 1989). KYNA also isosterically (competitively) antagonizes non-NMDA receptor-gated ion channels (Kessler et al., 1989), while I2CA demonstrates selective antagonism of the glycine site (J. E. Hüettner, personal communication). Although I2CA has not previously been used as a potential therapeutic treatment for CNS injury, KYNA and/or 7-chloro-KYNA have been shown to (1) reverse glutamate neurotoxicity in cell culture (Shalaby et al., 1989), (2) be neuroprotective in models of in vitro hypoxia (Priestley et al., 1990), (3) attenuate both post-TBI increases in extracellular $\left[\mathrm{K}^{+}\right]$and increases in glucose utilization following microdialysis administration into the hippocampus (Katayama et al., 1990; Kawamata et al., 1992), (4) decrease stroke size following global ischemia (Germano et al., 1987), and (5) reduce neurologic motor deficits following traumatic spinal cord injury (Reynolds et al., 1989). However, the potential therapeutic effects of glycine site antagonists have not been investigated in models of experimental brain injury. Since experimental parasagittal fluid-percussion (FP) brain injury induces many features similar to those observed following human brain injury, including regional edema formation (Soares et al., 1992), neurologic motor dysfunction (McIntosh et al., 1989b), and cognitive deficits (Smith et al., 1991), we examined the effects of KYNA and I2CA on neurochemical changes (regional edema formation and changes in regional total tissue cation concentrations) and behavioral changes (neurologic motor dysfunction and memory dysfunction) following parasagittal FP brain injury in the rat.

\section{Materials and Methods}

Experimental brain injury. Male Sprague-Dawley rats $(350-400 \mathrm{gm}, n$ $=187)$ were anesthetized with sodium pentobarbital $(60 \mathrm{mg} / \mathrm{kg}$, i.p. 5 min after receiving $0.06 \mathrm{mg}$ of atropine (i.m.) (animals typically remain anesthetized for 90-100 min). Once surgically anesthetized, the animals were placed in a stereotaxic frame, the scalp and temporal muscle were reflected, and a $2.0 \mathrm{~mm}$ hollow female Luer-Lok fitting was rigidly fixed with dental cement into a craniotomy centered above the left parietal cortex, $5 \mathrm{~mm}$ anterior to lambda, $5 \mathrm{~mm}$ posterior to bregma, and $4 \mathrm{~mm}$ lateral to the sagittal suture. The dura was left intact at this opening. Ninety minutes following pentobarbital administration, lateral (parasagittal) experimental brain injury was induced using a lateral fluidpercussion model (McIntosh et al., 1989b). Briefly, the FP injury device is connected to the animal via the female Luer-Lok fitting. The device produces a pulse of increased intracranial pressure of $21-23 \mathrm{msec}$ duration through the rapid injection of saline into the closed cranial cavity, resulting in brief displacement and deformation of neural tissue. This pressure pulse is measured extracranially by a transducer (Gould, Inc.) housed in the injury device, and displayed on a storage oscilloscope. The pressure pulse is recorded in atmospheres (atm), with animals receiving brain injury of moderate severity (2.5-2.6 atm). Control "sham" animals received surgical preparation without FP brain injury.

Evaluation of cognitive function. Evaluation of post raumatic memory function was performed using an adaption of the Morris water maze (MWM) paradigm (Morris, 1984). The MWM used is a circular tank ( $1 \mathrm{~m}$ in diameter and $50 \mathrm{~cm}$ deep) filled to $25 \mathrm{~cm}$ with $18^{\circ} \mathrm{C}$ water, which is covered with Styrofoam pieces to render the surface opaque. A stationary, submerged and nonvisible platform $11.5 \mathrm{~cm}$ square and $24 \mathrm{~cm}$ tall $(1 \mathrm{~cm}$ below the surface) is placed in a site determined from a grid design of various zones (Fig. 1, zone A). This grid design, con- structed with a computerized video system (video-scan lab animal monitoring system, Omnitech Electronics, Inc.) is superimposed over the maze and viewed on a monitor. Animals $(n=82)$ were trained in the MWM to locate the platform using external visual cues. Each animal was given 20 training trials over $2 \mathrm{~d}$ immediately prior to brain injury; $2.5 \mathrm{hr}$ after the final trial all animals were anesthetized and subjected to FP brain injury or sham injury as described above. Fifteen minutes following brain injury, animals randomly received a $1 \mathrm{ml}$ intravenous (femoral vein) infusion of either phosphate-buffered I2CA $(50 \mathrm{mg} / \mathrm{kg})$, phosphate-buffered I2CA ( $20 \mathrm{mg} / \mathrm{kg})$, phosphate-buffered KYNA (300 $\mathrm{mg} / \mathrm{kg}$ ), or phosphate buffer alone. The numbers of sham and injured animals/group are summarized in Table 1 . The $50 \mathrm{mg} / \mathrm{kg} \mathrm{I2CA-treated}$ group was only used for the memory and motor evaluation studies. The dose of KYNA was determined from previous in vivo CNS injury study (Germano et al., 1987); lower doses were not evaluated due to potentially poor blood-brain permeability of this hydrophilic compound. Doses of 12CA were determined from preliminary studies demonstrating an $L_{50}$ for $12 \mathrm{CA}$ at $100 \mathrm{mg} / \mathrm{kg}$ with maximal nonlethal dose at approximately $50 \mathrm{mg} / \mathrm{kg}$. It is important to note that although the halogenated derivatives of KYNA and I2CA appear more potent in vitro (Kemp et al., 1988; Hüettner, 1989), preliminary studies in our laboratory demonstrated that intravenous administration of 5-fluoro-I2CA did not produce behavioral characteristics consistent with NMDA receptor antagonism as did I2CA at equal intravenous doses (ataxia at $20-50 \mathrm{mg} / \mathrm{kg}$, unconsciousness and respiratory depression at $50-100 \mathrm{mg} / \mathrm{kg}$ ). Although available, the halogenated derivatives of KYNA were prohibitively expensive at the doses needed for in vivo administration and therefore were not evaluated.

Forty-two hours postinjury, animals were tested for their ability to remember the preinjury learned task in the MWM. The platform was removed, and the animals were given a 1 min test period in the MWM, while the computerized-video unit recorded their swimming patterns. Each zone of the computerized grid design is ranked in a weighted fashion according to its proximity to the platform. These assigned numbers are multiplied by the number of seconds spent in the corresponding zone and totaled. The ranked numbers, depicted in Figure 1, are derived from a series of studies designed to assess the behavioral characteristics of trained injured and noninjured animals searching for the platform (Smith et al., 1991). Since animals that receive a more severe brain injury have more of a tendency to swim along the periphery of the tank, zone $\mathrm{D}$ is scored as a function of the time spent in zone $\mathrm{D}$ divided by that spent in zone $G$ (peripheral zonc) (Fig. 1). Escape latencies (time used initially to cross through the platform site, zone A), were also recorded. This modification of the Morris water maze has been used successfully by us to characterize cognitive deficits following experimental brain injury (Smith et al., 1991, 1992; Okiyama et al., 1992).

Evaluation of neurologic motor function. Evaluation of chronic posttraumatic motor dysfunction of animals also used for the memory study was assessed at $24 \mathrm{hr}, 1$ week, and 2 weeks after injury. Neurologic function is evaluated using previously described paradigms (Dixon et al., 1987; McIntosh et al., 1987, 1989b) by a trained observer who is unaware of each animal's treatment. Animals are scored from 4 (normal) to 0 (severely impaired) for each of the following indices: (1) right and left forelimb flexion response during suspension by the tail (highest possible score $=8) ;(2)$ decreased resistance to left and right lateral pulsion (highest possiblc scorc $=8$ ); (3) ability to stand on an inclined angle board in the vertical and right and left horizontal positions, with the maximal angle at which the animal can stand for $5 \mathrm{sec}$ recordedanimals are scored in regard to their change in angle from baseline data, where $0^{\circ}=4,2.5^{\circ}=3,5^{\circ}=2,7.5^{\circ}=1,10^{\circ}$ or more $=0$ (highest possible score $=12$ ); and (4) movement across a grid field both vertically and horizontally as measured by a computerized activity monitor (OptoVarimax, Columbus Instruments). Spontaneous locomotor activity, both stereotypic and ambulatory, is recorded and activity scores calculated: $89-100 \%$ of baseline activity $=4,78-88 \%$ of baseline $=3.5,67-77 \%$ of baseline $=3,56-66 \%$ of baseline $=2.5,45-55 \%$ of baseline $=2,34$ $44 \%$ of baseline $=1.5,23-33 \%$ of baseline $=1,12-22 \%$ of baseline $=$ 0.5 , and $0-11 \%$ of baseline $=0$ (highest possible score $=8$ ). A total composite functional neurologic score $(0-36)$ is obtained by combining the scorcs for cach of the four neurobchavioral tests.

Evaluation of cerebral edema. For cerebral edema determination, animals were randomly administered a $1 \mathrm{ml}$ volume of either $12 \mathrm{CA}(20$ $\mathrm{mg} / \mathrm{kg}$, i.v.), KYNA (300 mg/kg, i.v.), or phosphate buffer (i.v.) $15 \mathrm{~min}$ following injury or sham treatment. The numbers of sham and injured animals/group are summarized in Table 1. These animals were reanesthetized with sodium pentobarbital $(200 \mathrm{mg} / \mathrm{kg}$, i.p.) at $48 \mathrm{hr}$ fol- 


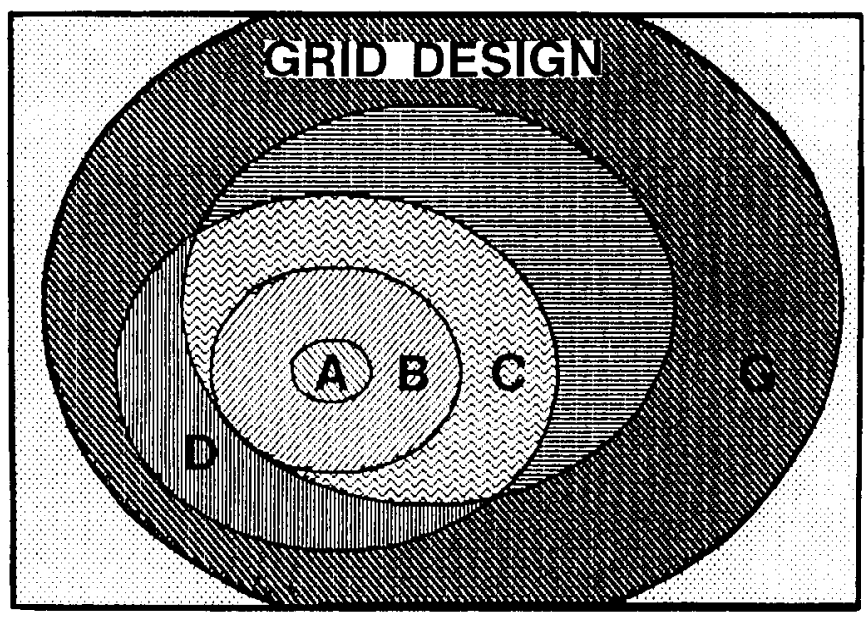

Figure 1. Computerized grid design superimposed over the water maze during $1 \mathrm{~min}$ memory test. Discrete zoncs are labeled with letters, zonc $A$ representing the platform site. Memory scores derived from the formula (time in zone $A \times 20)+($ time in zone $B \times 5)+($ time in zone $\mathrm{C} \times 2)+[($ time in zone $\mathrm{D} /$ time in zone $\mathrm{G}) \times 35]=$ memory score.

lowing FP brain injury and killed by decapitation ( $48 \mathrm{hr}$ following FP brain injury has been previously shown to be the time point of maximal edema formation in this model; Soares et al., 1992). The brains were rapidly removed and dissected on a chilled marble plate into the following regions: injured left parietal cortex (maximal injury site), cortex adjacent to maximal injury (adjacent site), contralateral right parietal cortex (contralateral cortex), bilateral hippocampi and thalami (Fig. 2). Tissue samples were transferred to a cooled humid box. Brain water content was cvaluated by the wct wcight/dry wcight technique: fresh tissue samples were weighed on aluminum foil, dried for $24 \mathrm{hr}$ at $100^{\circ} \mathrm{C}$, and then reweighed. Percentage of water was calculated as [(wet weight - dry weight)/wet weight] $\times 100$. In our laboratory, this technique has proven to be an extremely sensitive and reproducible method for the evaluation of regional cerebral edema formation after brain injury (Okiyama et al., 1992; Soares et al., 1992).

Evaluation of total tissue cation concentrations. The dried tissue samples derived from the edema studies were placed in plastic tubes containing $2 \mathrm{ml}$ of $2 \mathrm{M}$ nitric acid and $1 \%$ lanthanum oxide and dissoluted in an ultrasonic water bath for $24 \mathrm{hr}$. The tubes were then removed from the water bath, and the volume was filtered $(0.8 \mu \mathrm{M}$, MILLEX) and diluted with $1 \%$ lanthanum oxide in $0.6 \mathrm{M}$ hydrochloric acid until the concentration of each cation was within the appropriate sensitivity range of the atomic absorption spectrophotometer. Total concentrations of sodium ([Na]), potassium ([K]), calcium ([Ca]), magnesium $([\mathrm{Mg}])$, and zinc $([\mathrm{Zn}])$ of dried tissue samples were measured by using a PerkinElmer model 1100 B Atomic Absorption Spectrophotometer with an air-acetylene flame. The absorptions of $[\mathrm{Na}],[\mathrm{K}],[\mathrm{Ca}],[\mathrm{Mg}]$, and $[\mathrm{Zn}]$ were determined at $589.6,766.5,422.7,285.2$, and $213.9 \mathrm{~nm}$, respectively. Tissue ion concentrations were expressed as $\mu \mathrm{mol} / \mathrm{gm}$ wet tissue weight. Changes in brain cation concentrations following lateral fluidpercussion brain injury using these techniques have been previously reported (Thomas et al., 1990; Soares et al., 1992).

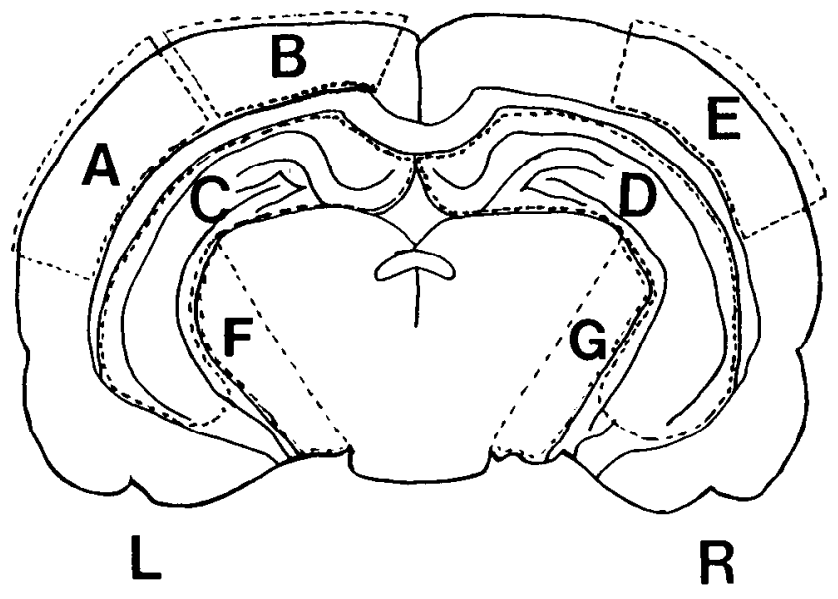

Figure 2. Schematic coronal representation of brain regions dissected after brain injury for cerebral edema and total tissue cation analysis. Region $A$ is the site of maximal injury in the parietotemporal cortex; region $B$ is the cortex adjacent (dorsolateral) to the site of maximal injury; regions $C$ and $D$ are the ipsilateral (to site of maximal injury) and contralateral hippocampus, respectively; region $E$ is the contralateral cortex; and regions $F$ and $G$ are the ipsilateral and contralateral ventrolateral thalamus, respectively.

Evaluation of brain and core body temperature. Since core brain temperature has been shown to correlate directly with temporalis muscle temperature (Corbett et al., 1990), $1 \mathrm{hr}$ prior to FP brain injury or sham treatment, a needle temperature probe (YSI Inc.) was inserted into a the right temporalis muscle of animals. In addition, a rectal temperature probe was also inserted $1 \mathrm{hr}$ prior to brain injury or sham treatment for measurement of core body temperature. $\Lambda$ nimals received a $1 \mathrm{ml}$ intravenous injection of either I2CA $(50 \mathrm{mg} / \mathrm{kg}$ or $20 \mathrm{mg} / \mathrm{kg}), \mathrm{KYNA}$ $(300 \mathrm{mg} / \mathrm{kg}$ ), or phosphate buffer. The numbers of sham and injured animals/group are summarized in Table 1 . Temperature readings from both probes were recorded every $5 \mathrm{~min}$ for $3 \mathrm{hr}$ following brain or sham injury and drug administration.

Data analysis. All data are expressed as means \pm SEM, except for behavioral assessment scores (ordinal data), which are expressed as median values. Continuous variables are compared across groups by analysis of variance (ANOVA) followed by Student-Newman-Keuls tests. Ordinal measurements such as neurologic motor scores and memory scores were evaluated using nonparametric Kruskal-Wallis ANOVA followed by individual Mann-Whitney $U$ tests. Survival was determined from the animals used for the memory and neurologic motor studies, which were observed for 2 weeks following brain injury. Differences in survival between treatment groups were compared using Fisher's exact probability test. A $p$ value of less than 0.05 was considered statistically significant.

\section{Results}

FP brain injury induced a profound memory loss of the preinjury learned task, as demonstrated by a greater than fivefold decrease in median memory score of the injured buffer-treated group

Table 1. Distribution of animals per treatment group for each study

\begin{tabular}{|c|c|c|c|c|c|c|c|c|c|}
\hline \multirow[b]{2}{*}{ Study } & \multicolumn{2}{|l|}{ Buffer } & \multicolumn{2}{|c|}{$\begin{array}{l}12 \mathrm{CA} \\
(50 \mathrm{mg} / \mathrm{kg})\end{array}$} & \multicolumn{2}{|c|}{$\begin{array}{l}12 \mathrm{CA} \\
(20 \mathrm{mg} / \mathrm{kg})\end{array}$} & \multicolumn{2}{|c|}{$\begin{array}{l}\text { KYNA } \\
(300 \mathrm{mg} / \mathrm{kg})\end{array}$} & \multirow[b]{2}{*}{ Total } \\
\hline & Sham & Injured & Sham & Injured & Sham & Injured & Sham & Injured & \\
\hline $\begin{array}{c}\text { Memory/neurologic } \\
\text { motor evaluation }\end{array}$ & 12 & 14 & 6 & 16 & 6 & 14 & 6 & 14 & 88 \\
\hline Edema/cations & 12 & 13 & - & - & - & 12 & - & 14 & 51 \\
\hline $\begin{array}{l}\text { Core body and } \\
\text { brain temperature }\end{array}$ & 6 & 6 & 6 & 6 & 6 & 6 & 6 & 6 & 48 \\
\hline
\end{tabular}

Data are presented as the number of animals in each treatment group. 


\section{MEMORY TEST}
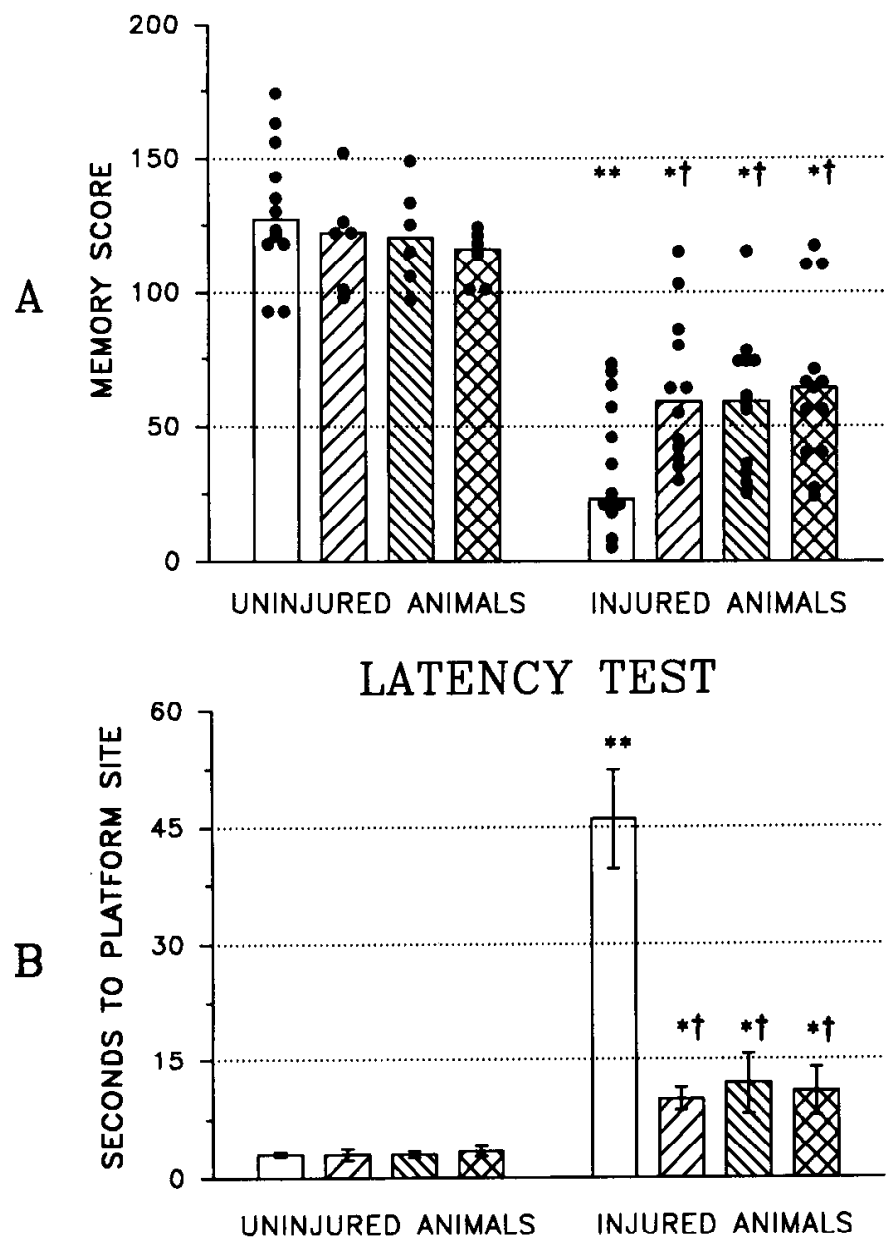

$\begin{array}{ll}\square \text { BUFFER } & \text { IV I2CA } 20 \mathrm{mg} / \mathrm{kg} \\ \square D \text { 12CA } 50 \mathrm{mg} / \mathrm{kg} & X X \text { KYNA } 300 \mathrm{mg} / \mathrm{kg}\end{array}$

Figure 3. A, Median memory scores $42 \mathrm{hr}$ after FP brain injury of sham and injured, buffer-treated and drug-treated animals. Dots represent individual scores. $B$, Mean latency scores (time taken to locate platform site) of same groups. Error bars represent SEM. ${ }^{*}, p<0.01$ compared to buffer-treated uninjured animals; ${ }^{* *}, p<0.001$ compared to buffer-treated uninjured animals; $\dagger, p<0.01$ compared to buffertreated injured animals.

compared to the uninjured buffer-treated group $(p<0.001)$ (Fig. 3A). This memory loss was significantly attenuated in injured groups treated at 15 min postinjury with either I2CA (50 $\mathrm{mg} / \mathrm{kg}$ or $20 \mathrm{mg} / \mathrm{kg}$ ) or KYNA $(300 \mathrm{mg} / \mathrm{kg}$ ), with a more than doubling of median memory scores compared with injured buffer-treated controls ( $p<0.02$ for multivariate comparison; $p<$ 0.01 for individual comparisons) (Fig. $3 A$ ). Sham uninjured animals treated with $12 \mathrm{CA}(50 \mathrm{mg} / \mathrm{kg}$ or $20 \mathrm{mg} / \mathrm{kg})$ or KYNA $(300 \mathrm{mg} / \mathrm{kg})$ showed no significant difference in memory scores compared to the buffer-treated sham groups. A significant increase (worsening) in water maze latency scores observed between sham buffer-treated and injured buffer-treated animals ( $p$ $<0.001)$ was also reversed in the drug-treated injured animals compared to vehicle-treated injured controls $(p<0.01)$ (Fig. $3 B)$. Drug treatment in sham animals showed no significant

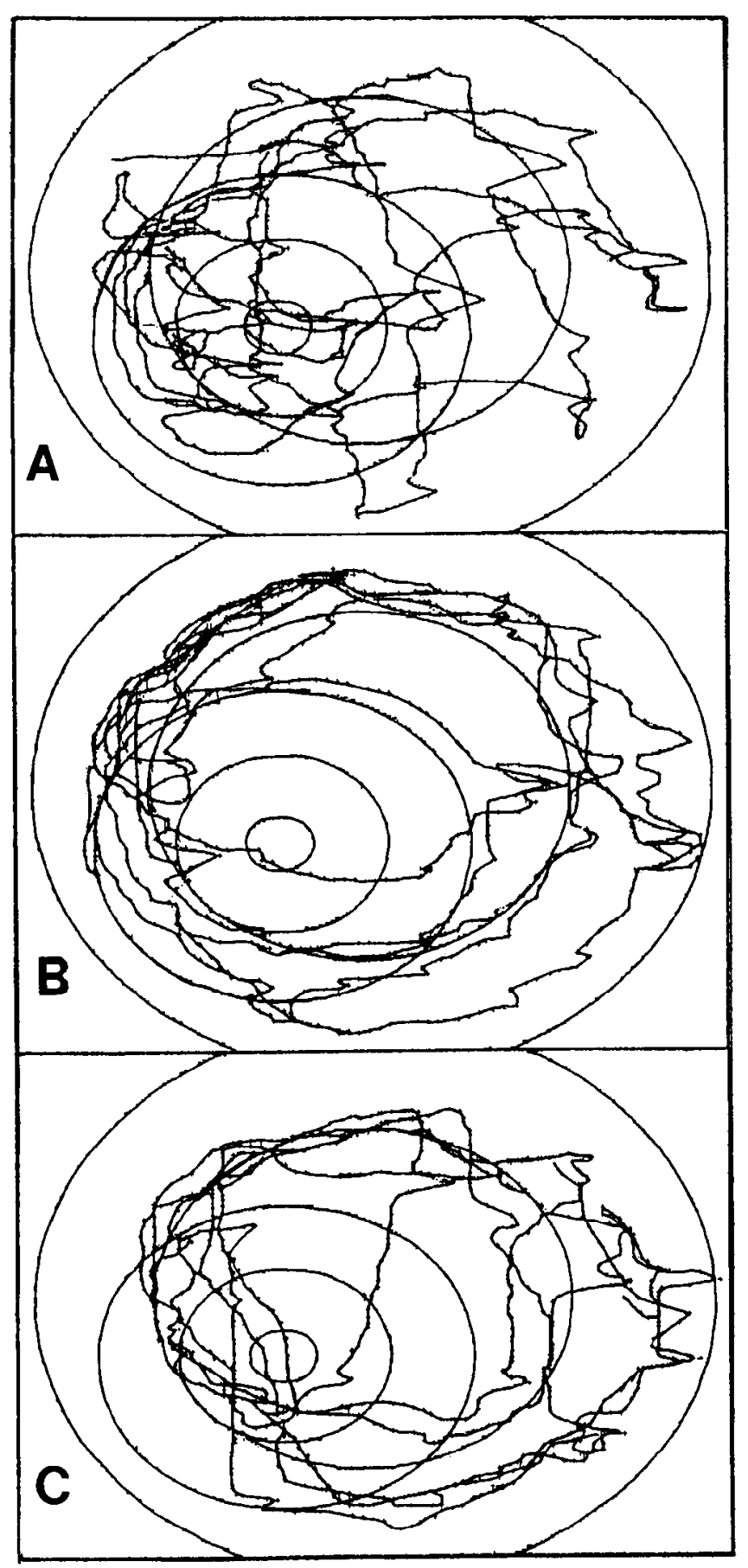

Figure 4. Representative activity (swimming) patterns of animals with memory scores near the median of their respective groups. $A$, Uninjured buffer-treated animal; memory score $=125$, latency score $=2 \mathrm{sec} . B$, Injured buffer-treated animal; memory score $=23$, latency score $=16$ sec. $C$, Injured KYNA $(300 \mathrm{mg} / \mathrm{kg})$-treated animal (representative of animals scoring near the median from all drug-treated groups); memory score $=62$, latency score $=11 \mathrm{sec}$.

cffect on latency (Fig. 3B). Representative tracings of swimming patterns of animals scoring near the median of their respective groups are shown in Figure 4. Injured animals treated only with buffer typically showed little "platform seeking" behavior (Fig. $4 B$ ). However, animals that received drug treatments clearly retained memory of the location of the platform site (Fig. $4 C$ ), although this memory was still considerably less acute than the memory of uninjured animals (Fig. 4A). 
FP brain injury in buffer-treated animals also induced significant and prolonged $(p<0.001)$ neurologic motor dysfunction compared to sham buffer-treated animals, when measured at $24 \mathrm{hr}, 1$ week, and 2 weeks following brain injury (Fig. $5 \mathrm{~A}-$ $C)$. Although no significant effects on neurologic motor scores were observed in any of the drug treatment groups compared to buffer-trcated injured animals in the early posttraumatic period ( $24 \mathrm{hr}$ or 1 week following brain injury), by 2 weeks postinjury, animals treated with I2CA ( $50 \mathrm{mg} / \mathrm{kg}$ or $20 \mathrm{mg} / \mathrm{kg}$ ) and KYNA $(300 \mathrm{mg} / \mathrm{kg}$ ) demonstrated a significant reduction of neurologic motor deficits as reflected by an improvement in composite motor scores $(p<0.03$ for multivariate comparison; $p<0.05$ for individual comparisons) (Fig. $5 C$ ).

Forty-eight hours following FP brain injury, significant edema formation was observed in all brain regions evaluated. Analysis of the left hippocampus, site of maximal injury in the left cortex, cortex adjacent to maximal injury, and left thalamus showed more pronounced edema formation $(p<0.001)$ (Fig. $6 A$ ), while analysis of the right hippocampus, right cortical site contralateral to maximal injury site, and right thalamus revealed a significant increase in tissue water content of a lesser magnitude $(p<0.05)$ (Fig. 6A). Treatment with $300 \mathrm{mg} / \mathrm{kg} \mathrm{KYNA} \mathrm{sig-}$ nificantly attcnuated the posttraumatic increase in tissue water content in the left hippocampus, cortex adjacent to the site of maximal injury, and left thalamus. Compared to KYNA-treated animals, a less dramatic, but similar pattern of reduced edema formation was observed in the $20 \mathrm{mg} / \mathrm{kg}$ I2CA-treated animals, which was significant only for the left thalamus. The regional edema formation in the site of maximal injury (left parietal cortex) was unaffected by either drug treatment (Fig. $6 B$ ).

Dramatic changes in regional cation homeostasis were demonstrated $48 \mathrm{hr}$ following FP brain injury of buffer-treated animals when compared to sham (uninjured) animals (Table 2). [Na] was significantly increased in both hippocampi, and in the maximal injury site and adjacent site in the left cortex. [K] was significantly decreased in the left hippocampus and site of maximal injury. [Ca] was significantly increased in all areas tested, while $[\mathrm{Mg}]$ was significantly reduced in the left hippocampus and site of maximal injury. [Zn] was also significantly reduced following injury in the left hippocampus, site of maximal injury, and adjacent site. The general pattern of changes in total tissue cation concentrations following brain injury tended toward an increase in $[\mathrm{Na}]$ and $[\mathrm{Ca}]$ and a decrease of $[\mathrm{K}],[\mathrm{Mg}]$, and $[\mathrm{Zn}]$ (Table 2). Treatment with either KYNA or I2CA had differential effects on posttraumatic changes in cation concentrations (Table 2). KYNA significantly attenuated increases in total tissue [Ca] throughout the brain and significantly attenuated the decrease in $[\mathrm{K}]$ in the left hippocampus. However, no significant effects on regional changes in $[\mathrm{Na}],[\mathrm{Mg}]$, or $[\mathrm{Zn}]$ were observed following KYNA treatment. Although I2CA had no significant effect on the posttraumatic increase of [Ca], it globally attenuated the decrease in $[\mathrm{K}]$. I2CA also significantly reduced posttraumatic increases in [Na] in both hippocampi and in the maximal injury site, and reversed the decrease of both $[\mathrm{Mg}]$ (left hippocampus) and $[\mathrm{Zn}]$ (adjacent site and left thalamus) (Table 2).

A decrease in temporalis muscle temperature (reflecting brain temperature) of $0.6^{\circ} \mathrm{C} \pm 0.05$ (mean $\pm \mathrm{SEM}$ ) was observed immediately following FP brain injury. This slight temperature decrease typically resolved by $30 \mathrm{~min}$ following injury. Core body temperature, however, did not change following brain injury. Treatment with either I2CA $(50 \mathrm{mg} / \mathrm{kg}$ or $20 \mathrm{mg} / \mathrm{kg})$ or

\section{COMPOSITE NEUROSCORE}
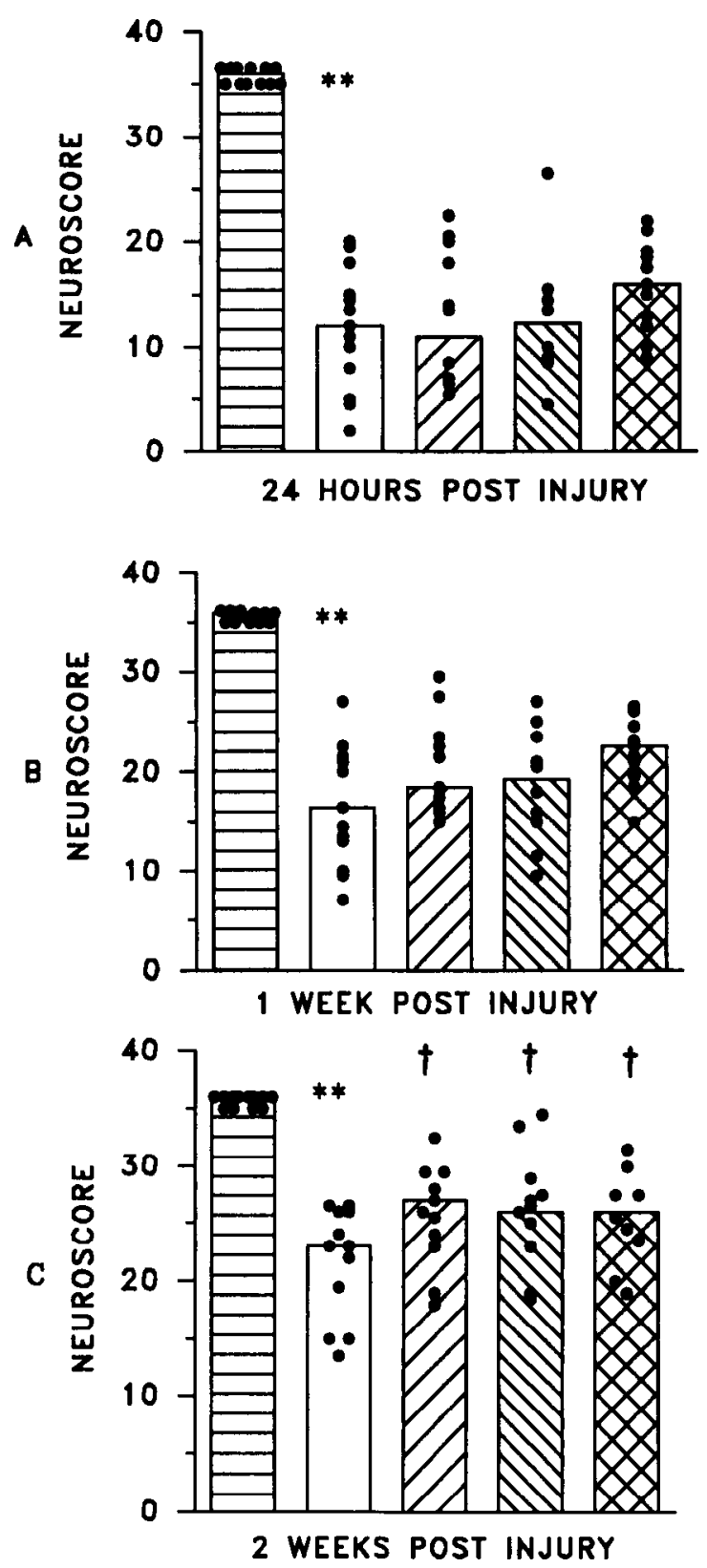

UNINJURED CONTROLS
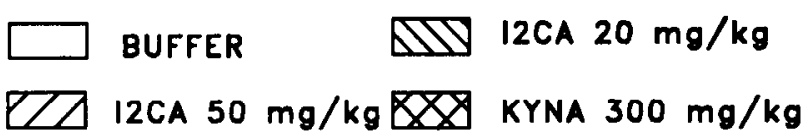

Figure 5. Mean composite neurologic motor scores of sham and injured, buffer-treated, and drug-treated animals, evaluated at $24 \mathrm{hr}(A)$, 1 week $(B)$, and 2 weeks $(C)$ after FP brain injury. Dots represent individual scores. ${ }^{* *}, p<0.001$ compared to buffer-treated uninjured animals; $\dagger, p<0.05$ compared to buffer-treated injured animals.

KYNA $(300 \mathrm{mg} / \mathrm{kg})$ had no effect on temporalis muscle or core body temperature following injury compared to buffer-treated animals. In sham uninjured animals, administration of the I2CA $(50 \mathrm{mg} / \mathrm{kg}$ or $20 \mathrm{mg} / \mathrm{kg}$ ) and KYNA $(300 \mathrm{mg} / \mathrm{kg})$ also had no effect on the temporalis muscle or core body temperature. 


\section{EDEMA \\ 48 HOURS POST INJURY}

SHAM BUFFER TREATED VS. INJURED BUFFER TREATED

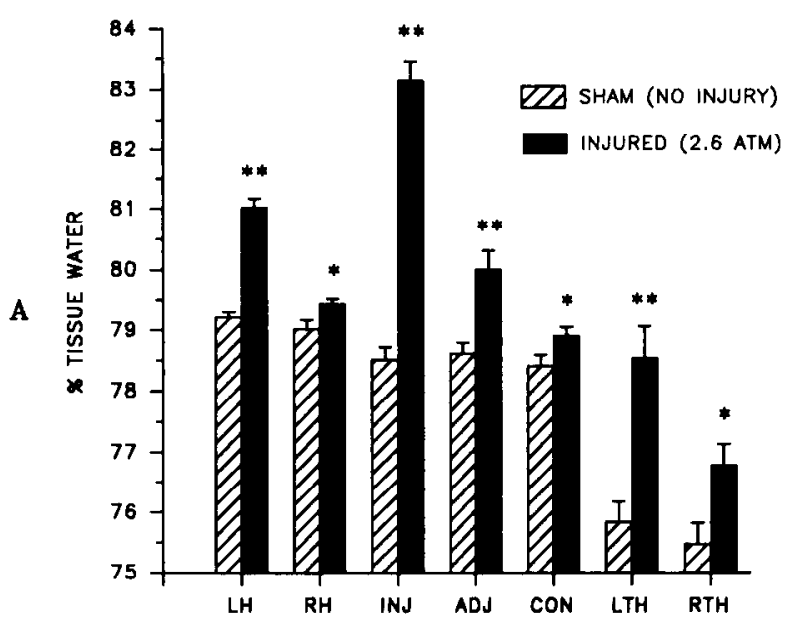

INJURED DRUG TREATED VS. INJURED BUFFER TREATED

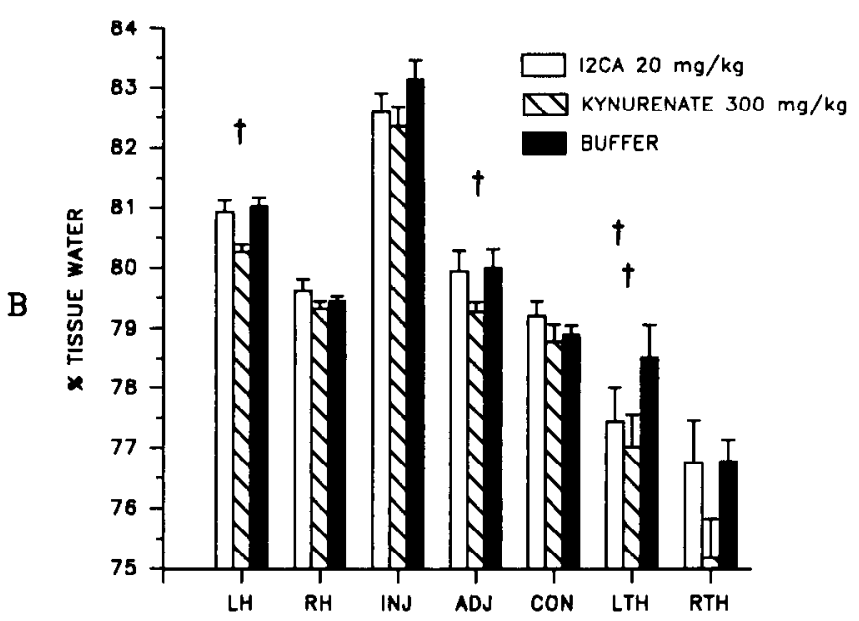

Figure 6. A, Effect of FP brain injury on regional water content $48 \mathrm{hr}$ following injury. $B$, Effect of I2CA and KYNA on regional water content $48 \mathrm{hr}$ following FP brain injury. Data are expressed as mean percentage of water per gram of tissue. Error bars represent SEM. ${ }^{*}, p<0.05$ compared to uninjured animals; ${ }^{* *}, p<0.001$ compared to uninjured animals; $\dagger, p<0.05$ compared to buffer-treated injured animals.

Analysis of postinjury and/or posttreatment mortality (assessing 88 animals used for memory and neurologic motor studies) revealed that none of the 30 sham uninjured animals, regardless of treatment, died over the 2 week period. Of the 58 brain-injured animals in these studies, 4 of $16(25 \%)$ I2CA (50 $\mathrm{mg} / \mathrm{kg}$ )-treated animals died, 2 of $14(14 \%)$ I2CA $(20 \mathrm{mg} / \mathrm{kg})-$ treated animals died, 1 of $14(7 \%)$ KYNA $(300 \mathrm{mg} / \mathrm{kg})$-treated animals died, and 1 of $14(7 \%)$ buffer-treated animals died. These differences were not statistically significant. None of the 51 animals used in the $48 \mathrm{hr}$ postinjury edema and cation studies or the 48 animals used in the acute brain and core body temperature studies died.

\section{Discussion}

The results of the present study demonstrate that administration of I2CA and KYNA may exert therapeutic effects following experimental brain injury by (1) attenuating cognitive deficits, (2) improving neurologic motor dysfunction, (3) reducing localized cerebral edema formation, and (4) reversing, in certain areas, posttraumatic changes in regional cation homeostasis. To our knowledge, this is the first report to demonstrate the efficacy of NMDA receptor antagonists on memory function following experimental TBI.

NMDA receptor-associated glycine site modulation has been shown to affect binding properties at other domains within the NMDA receptor. Uniquely, activation of the glycine site not only potentiates NMDA receptor binding, but also enhances binding of noncompetitive antagonists within the associated ionophore (Reynolds et al., 1987; Kessler et al., 1989). Conversely, antagonism of the glycine site inhibits binding of NMDA receptor ligands and may indirectly inhibit the binding of ligands to affinity sites within the ionophore (McDonalds et al., 1990). In addition, agonists acting at the glycine site have been shown to have substantial enhancing effects on learning and memory presumably, by enhancing potentiation of the NMDA receptor (Handelman et al., 1989; Monahan et al., 1989; Herberg and Rose, 1990). The absolute requirement of glycine binding for NMDA receptor activation along with the potential modulatory capabilities by glycine site ligands at other binding domains within the NMDA receptor may explain the dramatic effects of both I2CA and KYNA on posttraumatic outcome in the present study.

Memory dysfunction has been described as one of the most debilitating and distressing features following human TBI (Parkin, 1984; Levin, 1985). However, few experimental studies, evaluating the efficacy of pharmacologic agents in the treatment of TBI utilize memory function as an outcome parameter. Clinical and experimental studies have shown that bilateral damage to key structures in the hrain, including the hippocampus, may play a major role in the development of posttraumatic memory disorders (Zola-Morgan et al., 1986). In particular, the hippocampus has been shown to be an integral modulator of memory function (Scoville and Milner, 1957) and appears to be involved selectively with spatial learning and memory (Olton et al., 1978; Morris et al., 1982).

The neuronal cell loss observed in the hippocampus following various models of CNS injury has been described as disproportionate compared to damage in adjacent structures, suggesting that the hippocampus is selectively vulnerable to hypoxic or traumatic insults (Brierly, 1976; Pulsinelli et al., 1982; Cortez et al., 1989; Kotapka et al., 1991; Lowenstein et al., 1992). Intracerebral microdialysis techniques have demonstrated a marked increase in glutamate concentration in the cxtracellular space following CNS trauma (Faden et al., 1989; Katayama et al., 1990; Nilsson et al., 1990), which appears to result mainly from a massive release from presynaptic stores and not due to traumatically induced capillary permeability of glutamate from the blood into the extracellular space (Katayama et al., 1990). The excessive increase in extracellular glutamate is thought to induce a pathologic overactivation of EAA receptor subtypes, including the NMDA receptor (Rothman and Olney, 1986; Choi et al., 1987).

The hippocampus contains the highest concentration of NMDA receptors in the brain (Monaghan and Cotman, 1986), 
Table 2. Regional total tissue cation concentrations 48 hr following FP brain injury and treatment

\begin{tabular}{|c|c|c|c|c|c|c|c|c|}
\hline & & L Hipp & R Hipp & Inj Ctx & Adj Ctx & Con Ctx & L Thal & R Thal \\
\hline \multirow[t]{4}{*}[\mathrm{Na}]{} & SHAM & $37.3 \pm 1.6$ & $36.1 \pm 2.3$ & $40.4 \pm 2.1$ & $42.3 \pm 1.7$ & $39.1 \pm 2.0$ & $40.1 \pm 2.1$ & $41.3 \pm 2.8$ \\
\hline & BUFF & $56.2 \pm 2.3^{* *}$ & $46.4 \pm 3.0^{*}$ & $75.5 \pm 2.4^{* *}$ & $52.8 \pm 2.8^{* *}$ & $41.8 \pm 3.6$ & $47.2 \pm 5.0$ & $46.9 \pm 3.3$ \\
\hline & $12 \mathrm{CA}$ & $49.7 \pm 1.0 \dagger$ & $41.7 \pm 1.2$ & $64.9 \pm 1.8 \ddagger$ & $48.5 \pm 0.8$ & $40.8 \pm 1.5$ & $45.4 \pm 2.8$ & $47.2 \pm 5.2$ \\
\hline & KYNA & $52.4 \pm 2.3$ & $43.0 \pm 2.6$ & $72.4 \pm 2.4$ & $50.3 \pm 2.8$ & $39.4 \pm 1.6$ & $48.1 \pm 4.0$ & $47.2 \pm 4.0$ \\
\hline \multirow[t]{4}{*}{ [K] } & SHAM & $87.3 \pm 3.5$ & $86.6 \pm 4.9$ & $84.3 \pm 2.8$ & $83.2 \pm 4.2$ & $89.1 \pm 8.8$ & $90.4 \pm 3.4$ & $91.2 \pm 4.8$ \\
\hline & BUFF & $68.7 \pm 3.2^{* *}$ & $86.5 \pm 2.9$ & $50.6 \pm 3.4^{* *}$ & $76.9 \pm 3.7$ & $86.2 \pm 3.7$ & $78.5 \pm 3.6^{*}$ & $77.0 \pm 5.7^{*}$ \\
\hline & $12 \mathrm{CA}$ & $76.5 \pm 1.3 \dagger$ & $87.6 \pm 0.79$ & $63.1 \pm 2.4 \ddagger$ & $84.0 \pm 1.5 \dagger$ & $90.8 \pm 5.4$ & $90.3 \pm 2.0 \dagger$ & $90.1 \pm 2.1 \dagger$ \\
\hline & KYNA & $77.2 \pm 4.3 \dagger$ & $86.3 \pm 3.9$ & $58.8 \pm 4.3$ & $75.1 \pm 4.4$ & $85.2 \pm 3.8$ & $78.4 \pm 4.2$ & $82.4 \pm 5.0$ \\
\hline \multirow[t]{4}{*}{ [Ca] } & SHAM & $2.3 \pm 0.33$ & $2.4 \pm 0.29$ & $2.1 \pm 0.29$ & $2.5 \pm 0.46$ & $2.2 \pm 0.26$ & $3.1 \pm 0.51$ & $3.2 \pm 0.69$ \\
\hline & BUFF & $5.0 \pm 0.41^{* *}$ & $4.3 \pm 0.63^{*}$ & $7.9 \pm 1.0^{* *}$ & $7.5 \pm 0.81^{* *}$ & $4.1 \pm 0.55^{* *}$ & $10.1 \pm 1.4^{* *}$ & $8.2 \pm 1.4^{*}$ \\
\hline & $12 \mathrm{CA}$ & $5.0 \pm 0.42$ & $4.2 \pm 0.17$ & $5.7 \pm 0.48$ & $6.6 \pm 0.56$ & $4.4 \pm 0.61$ & $10.4 \pm 1.2$ & $9.0 \pm 1.2$ \\
\hline & KYNA & $3.4 \pm 0.34 \dagger$ & $3.4 \pm 0.51$ & $5.8 \pm 0.53$ & $5.0 \pm 0.61 \dagger$ & $2.2 \pm 0.28 \dagger$ & $6.1 \pm 1.1 \dagger$ & $7.3 \pm 1.4$ \\
\hline \multirow[t]{4}{*}[\mathrm{Mg}]{} & SHAM & $6.3 \pm 0.13$ & $6.1 \pm 0.41$ & $6.5 \pm 0.44$ & $6.1 \pm 0.10$ & $6.0 \pm 0.21$ & $6.7 \pm 0.17$ & $6.6 \pm 0.18$ \\
\hline & BUFF & $5.4 \pm 0.20^{* *}$ & $6.2 \pm 0.11$ & $4.6 \pm 0.18^{* *}$ & $6.1 \pm 0.23$ & $6.1 \pm 0.21$ & $6.6 \pm 0.28$ & $6.6 \pm 0.34$ \\
\hline & $12 \mathrm{CA}$ & $5.9 \pm 0.07 \dagger$ & $6.3 \pm 0.09$ & $5.0 \pm 0.18$ & $6.0 \pm 0.18$ & $6.1 \pm 0.13$ & $6.8 \pm 0.33$ & $6.5 \pm 0.42$ \\
\hline & KYNA & $5.7 \pm 0.16$ & $5.9 \pm 0.44$ & $4.8 \pm 0.22$ & $5.9 \pm 0.17$ & $6.0 \pm 0.19$ & $6.5 \pm 0.66$ & $6.7 \pm 0.56$ \\
\hline \multirow[t]{4}{*}[\mathrm{Zn}]{} & SHAM & $0.43 \pm 0.05$ & $0.42 \pm 0.06$ & $0.39 \pm 0.04$ & $0.40 \pm 0.04$ & $0.40 \pm 0.03$ & $0.32 \pm 0.08$ & $0.31 \pm 0.09$ \\
\hline & BUFF & $0.29 \pm 0.02 *$ & $0.31 \pm 0.04$ & $0.27 \pm 0.03^{*}$ & $0.30 \pm 0.03^{*}$ & $0.31 \pm 0.04$ & $0.34 \pm 0.03$ & $0.35 \pm 0.05$ \\
\hline & $12 \mathrm{CA}$ & $0.31 \pm 0.02$ & $0.35 \pm 0.06$ & $0.27 \pm 0.02$ & $0.42 \pm 0.07 \dagger$ & $0.41 \pm 0.04$ & $0.46 \pm 0.05 \dagger$ & $0.45 \pm 0.06$ \\
\hline & KYNA & $0.29 \pm 0.02$ & $0.32 \pm 0.08$ & $0.25 \pm 0.03$ & $0.36 \pm 0.04$ & $0.29 \pm 0.03$ & $0.40 \pm 0.07$ & $0.35 \pm 0.08$ \\
\hline
\end{tabular}

Data are presented as $\mu \mathrm{mol} / \mathrm{gm}$ wet tissue weight (mean \pm SEM). L Hipp, left (ipsilateral) hippocampus; R Hipp, right (contralateral) hippocampus; Inj Ctx, site of maximal injury in the left parietotemporal cortex; Adj Ctx, cortex adjacent (dorsolateral) to maximal injury site; Con Ctx, contralateral cortical site; $\mathrm{L}$ Thal, left (ipsilateral) ventrolateral thalamus; $\mathbf{R}$ Thal, right (contralateral) ventrolateral thalamus. ${ }^{*}, p<0.05$, and ${ }^{* *}, p<0.01$, compared to uninjured animals; $\dagger, p<0.05$, and $\ddagger, p<0.01$, compared to buffer-treated injured animals. Statistical analysis of drug-treated animals compared to sham animals is not shown.

which may partially explain its selective vulnerability in models of CNS injury and the development of postinjury cognitive deficits. In addition to hippocampal cell loss following CNS injury, alterations in hippocampal NMDA receptor binding have also been observed following experimental brain injury (Miller et al., 1990). The dramatic preservation of memory function following postinjury I2CA and KYNA administration in the present study may be due to their ability to antagonize the NMDA receptor-associated glycine site, inhibiting NMDA receptor overactivation, especially in the hippocampus. Although KYNA may have also antagonized non-NMDA receptors, at the doses tested, KYNA was no more efficacious than 12CA in attenuating posttraumatic memory loss.

Previous reports have demonstrated attenuation of posttraumatic motor dysfunction following treatment with NMDA receptor antagonists, such as the noncompetitive NMDA receptor antagonists phencyclide (PCP) (Hayes et al., 1988), MK801 (McIntosh et al., 1989a, 1990; Shapira et al., 1991), and dextrorphan (Faden et al., 1989), and with the competitive NMDA antagonist 3-(2-carboxypiperazin-4yl)-propyl-1-phosphonic acid (CPP) (Faden et al., 1989). In the present study, we observed that glycine site antagonists may also be beneficial in the treatment of posttraumatic motor dysfunction. Although significant, the effects of I2CA and KYNA on motor function were not as dramatic as their effects on cognitive deficits. Previous studies have demonstrated that immediately following lateral FP brain injury, gross neuronal cell loss is observed in the left parietotemporal cortex (the focal site of injury, which includes the motor cortex), while cell loss in the hippocampus has been characterized as secondary or delayed, and is restricted to the CA2, CA3, and dentate hilar regions (Cortez et al., 1989; Lowenstein et al., 1992). The difference in efficacy of I2CA and KYNA observed between posttraumatic memory preservation and improvement of neurologic motor function may be related to differences in the extent of injury and the degree of primary versus secondary damage in the hippocampus compared to the motor cortex.

Although it is not clear why treatment with both doses of I2CA and the single dose of KYNA appeared equally efficacious on cognitive and neurologic motor outcome, these results may suggest that a maximal protective effect was reached by each treatment paradigm. Future studies will evaluate the efficacy of lower doses of these compounds to determine a potential concentration dependence of protection by I2C $\Lambda$ and KYNA.

In the present study, we observed marked regional cerebral edema formation and disturbances in cation homeostasis following lateral FP brain injury. These effects may have also resulted, in part, through trauma-induced overstimulation of EAA receptors. Choi and colleagues (Choi, 1988) have postulated that following CNS injury, (1) sustained excitation causes early intracellular accumulation of [ $\left.\mathrm{Na}^{\dagger}\right]$ (entering through non-NMDA receptors), which leads to acute neuronal swelling, and (2) $\left[\mathrm{Ca}^{2+}\right]$ influx (through the NMDA receptor-gated ionophore) causes a more delayed cascade of metabolic disturbances within the neuron. Recently it has been demonstrated that unique subpopulations of non-NMDA EAA receptors may also be permeable to $\left[\mathrm{Ca}^{2+}\right.$ ] (Iino et al., 1990; Hollmann et al., 1991) and it has been further postulated that non-NMDA receptors may also play an important role in the pathophysiology of CNS injury (Sheardown et al., 1990).

The regional cerebral edema formation observed in the present study was significantly reduced by KYNA (300 mg/kg) 
throughout the left hemisphere, where maximal edema formation has been observed following lateral FP brain injury (Soares et al., 1992). While I2CA demonstrated a similar pattern of edema reduction as KYNA, it only significantly reduced edema in the left thalamus. These differential effects on regional edema formation may be due to the differences in spectrums of antagonism of the two drugs. As a broad-spectrum EAA antagonist, KYNA may have attenuated $\left[\mathrm{Na}^{+}\right]$influx at both non-NMDA receptors and NMDA receptors following FP brain injury, while I2CA may have only blocked the influx of $\left[\mathrm{Na}^{+}\right]$through its more selective antagonistic actions at the NMDA receptor-associated glycine site. Although this effect might explain the differential efficacies of these two compounds on cytotoxic edema, our model of FP brain injury induces a considerable breakdown of the blood-brain barrier (Cortez et al., 1989; Soares et al., 1992) as well as profound and regional alterations in cerebral blood flow (Yamakami and McIntosh, 1989, 1991; Yuan et al., 1989), suggesting that vasogenic edema is also likely to be present. In previous studies, the maximal site of extravasation of blood following parasagittal FP brain injury has been observed in the left parietotemporal cortex. Although this region contained the greatest percentage of water following FP brain injury, KYNA showed no significant cffects at this site. This lack of effect by KYNA may be due to presence of extravasated blood at this site with accompanying vasogenic edema. In contrast to the extravasation of potentially deleterious blood-borne factors, disruption of the blood-brain barrier may have facilitated regional brain penetration of I2CA and KYNA, both hydrophilic compounds. However, enhanced delivery of these compounds may only be beneficial in regions not affected by overwhelming concomitant extravasation of toxic factors.

Corroborative evidence for the hypotheses of secondary neuronal swelling and pathologic changes in cation homeostasis has been observed in previous studies of parasagittal FP brain injury. These studies have demonstrated regional cerebral edema formation with concomitant changes in the homeostasis of total tissue cations, including an increase in [Na] and [Ca] and a decrease in [K] and [Mg] (Thomas et al., 1990; Okiyama et al., 1992; Soarcs ct al., 1992). Similar changes in [Na], [K], and [Ca] have also been observed after traumatic spinal cord injury (Young and Koreh, 1986) and cerebral ischemia (Young et al., 1986). The results of the present study support these previous observations, and extend the cation data to include regional decreases in the total tissue [ $\mathrm{Zn}$ ] following brain injury.

Further evidence of altered regional cation homeostasis following parasagittal FP brain injury has been observed using the intracerebral microdialysis technique, demonstrating a posttraumatic efflux of $\left[\mathrm{K}^{+}\right]$into the extracellular space (Katayama et al., 1990). In addition, a posttraumatic loss of intracellular free $\mathrm{Mg}^{2+}\left(\left[\mathrm{Mg}^{2+}\right]_{i}\right)$ from neurons has been observed using nuclear magnetic resonance spectroscopy (Vink et al., 1988). The posttraumatic increase in extracellular $\left[\mathrm{K}^{+}\right]$is thought to cause further release of EAAs (Hansen, 1987) through a mechanism dependent upon $\left[\mathrm{Ca}^{2+}\right]$ entry into nerve terminals (Somjen and Giacchino, 1985). Since both intraccllular and cxtraccllular $\left[\mathrm{Mg}^{2+}\right]$ have been shown to be important in the regulation of the NMDA receptor (Ascher and Nowak, 1988), a decrease in $\left[\mathrm{Mg}^{2+}\right]_{i}$ or total $\left[\mathrm{Mg}^{2+}\right]$ may signal a lost capacity for neurons to regulate EAA toxicity. Modulation of $\left[\mathrm{Zn}^{2+}\right]$ may also represent an important regulatory mechanism of the NMDA receptor. While $\left[\mathrm{Zn}^{2+}\right]$ has been shown to be released from brain tissue during activity (Assaf and Chung, 1984), $\left[\mathrm{Zn}^{2+}\right]$ has also been shown to reduce NMDA receptor-activated channel currents by acting at two distinct sites, one outside the membrane, possibly producing a noncompetitive antagonism of the glycine site (Yeh et al., 1990), and the other inside the channel, producing a faster voltage-dependent block than $\left[\mathrm{Mg}^{2+}\right]$ (Christine and Choi, 1990). Thus, the posttraumatic decrease of [Zn] observed in the present study may also indicate a pathologic response to EAA toxicity.

Although both I2CA and KYNA appeared efficacious in maintaining particular aspects of cation homeostasis following FP brain injury, these two distinct compounds demonstrated differential effects on individual cations. KYNA attenuated the increase in total tissue [Ca] throughout the brain and $[\mathrm{K}]$ in the left hippocampus, but had no significant effect on the changes in $[\mathrm{Na}],[\mathrm{Mg}]$, or $[\mathrm{Zn}]$. I2CA attenuated regional changes in the total tissue homeostasis of [Na], $[\mathrm{K}],[\mathrm{Mg}]$, and $[\mathrm{Zn}]$, but had no significant effect on posttraumatic alterations in [Ca]. These differential effects on cation homeostasis may also be related to differences in the spectrum of antagonism of these two compounds. The global effect of KYNA on [Ca] may be due to its ability to block $\left[\mathrm{Ca}^{2+}\right]$ entry into neurons by (1) antagonizing non-NMDA receptors, hence blocking depolarization, which would trigger the opening of voltage-gated NMDA receptors and voltage-sensitive calcium channels; (2) antagonizing unique $\left[\mathrm{Ca}^{2+}\right]$-permeable non-NMDA receptors; and 3) antagonizing the NMDA receptor at the associated glycine site. The potential mechanisms by which I2CA appeared more efficacious than KYNA in maintaining the total tissue [Na], $[\mathrm{K}],[\mathrm{Mg}]$, and $[\mathrm{Zn}]$ are not clear, but may reflect a difference in the modulation of the glycine site between these two compounds, in addition to the differences in action at non-NMDA receptors.

The lack of effect on brain temperature by $12 \mathrm{CA}(50 \mathrm{mg} / \mathrm{kg}$ or $20 \mathrm{mg} / \mathrm{kg}$ ) or KYNA $(300 \mathrm{mg} / \mathrm{kg})$ suggests that their therapeutic effects may have been due to direct antagonism of EAA receptors and not through indirect cerebral hypothermic effects, as has been suggested as the therapeutic mechanism of action of the noncompetitive NMDA antagonist MK801 in a models of gerbil cerebral ischemia (Buchan and Pulsinelli, 1990; Corbett et al., 1990).

The present data are consistent with the view that NMDA receptor antagonists may be useful in reversing the pathophysiologic sequelae of TBI. Treatment with novel glycine site antagonists following brain injury may prove unique by attenuating posttraumatic changes through their potential modulation of multiple binding sites. Moreover, although I2CA and KYNA may act differentially, both compounds demonstrated potential clinical utility with respect to the improvement of behavioral and neurochemical outcome following experimental brain injury.

\section{References}

Ascher P, Nowak L (1988) The role of divalent cations in the $\mathrm{N}$-methyl-D-aspartate responses of mouse central neurones in culture. J Physiol (Lond) 399:247-266.

Assaf SY, Chung SH (1984) Release of endogenous $\mathrm{Zn}^{2+}$ from brain tissue during activity. Nature 308:734-736.

Brierly JB (1976) Cerebral hypoxia. In: Greenfield's neuropathology (Blackwood W, Corsellis JAN, eds), pp 43-85. London: Arnold.

Buchan A, Pulsinelli WA (1990) Hypothermia but not the $N$-methylD-aspartate antagonist, MK-801, attenuates neuronal damage in gerbils subjected to transient global ischemia. J Neurosci 10:311-316.

Choi DW, Maulucci-Gedde MA, Kriegstein AR (1987) Glutamate neurotoxicity in cortical cell culture. J Neurosci 7:357-368. 
Choi DW (1988) Glutamate toxicity and diseases of the nervous system. Neuron 1:623-624.

Christine CW, Choi DW (1990) Effect of zinc on NMDA receptormediated channel currents in cortical neurons. J Neurosci 10:189116.

Collingridge GL, Bliss TVP (1987) NMDA receptors-their role in long-term potentiation. Trends Neurosci 10:288-293.

Corbett D, Evans S, Thomas C, Wang D, Jonas R (1990) MK801 reduced cerebral ischemic injury by inducing hypothermia. Brain Res 514:300-304.

Cortez SC, McIntosh TK, Noble LJ (1989) Vascular disruption and neuronal and glial alterations. Brain Res 482:271-282.

Dixon E, Lyeth B, Povlishock J, Findling R, Hamm R, Marmarou A, Hayes $R$ (1987) A fluid-percussion model of experimental brain injury in the rat. J Neurosurg 67:110-119.

Faden AI, Demediuk P, Panter SS, Vink R (1989) The role of excitatory amino acids and NMDA receptors in traumatic brain injury. Science 244:789-800.

Germano IM, Pitts LH, Meldrum BS, Bartkowski HM, Simon RP (1987) Kynurenate inhibition of cell excitation decreases stroke size and deficits. Ann Neurol 22:730-734.

Hamm RJ, Dixon C.F, Gbadeho DM, Singha AK, Jenkins LW, Lyeth BG, Hayes RL (1992) Cognitive deficits following traumatic brain injury by controlled cortical impact. J Neurotrauma 9:11-20.

Handleman GE, Nevins ME, Mueller SM, Arnolde SM, Cordi AA (1989) Milacemide, a glycine prodrug enhances performance of learning tasks in normal and amnestic rodents. Pharmacol Biochem Behav 34:823828.

Hansen AJ (1987) Effect of anoxia on ion distribution in the brain. Physiol Rev 65:101-148.

Harris EW, Ganong AH, Cotman CW (1984) Long-term potentiation in the hippocampus involves activation of $\mathrm{N}$-methyl-D-aspartate receptors. Brain Res 323:132-137.

Hayes RL, Jenkins L, Lyeth B, Balster RL, Robinson SE, Miller LP, Clifton GL, Young HF (1988) Pretreatment with phencyclidine, an $\mathrm{N}$-methyl-D-aspartate receptor antagonist, attenuates long-term behavioral deficits in the rat produced by traumatic brain injury. $J$ Neurotrauma 5:287-302.

Herberg LJ, Rose IC (1990) Effects of D-cycloserine and cycloleucine, ligands for the NMDA-associated strychnine-insensitive glycine site, on brain-stimulation reward and spontaneous locomotion. Pharmacol Biochem Behav 36:735-738.

Hollmann M, Hartley M, Heinemann S (1991) $\mathrm{Ca}^{2+}$ permeability of KA-AMPA-gated glutamate receptor channels depend on subunit composition. Science 252:851-853

Hüettner JE (1989) Indole-2-carboxylic acid: a competitive antagonist of potentiation by glycine at the NMDA receptor. Science 243:16111613.

Iino M, Ozawa S, Tsuzuki K (1990) Permeation of calcium through amino acid receptor channels in cultured rat hippocampal ncurons. J Physiol (Lond) 424:151-165.

Jenkins LW, Lyeth BG, LeWelt W, Moszynski K, DeWitt DS, Balster RL, Miller LP, Clifton GL, Young HF, Hayes RL (1988) Combined pre-trauma scopolamine and phencyclidine attenuates post-traumatic increased sensitivity to delayed secondary ischemia. J Neurotrauma 5:303-315.

Katayama Y, Becker DP, Tamura T, Hovda DA (1990) Massive increases in extracellular potassium and the indiscriminate release of glutamate following concussive brain injury. J Neurosurg 73:889900.

Kawamata T, Katayama Y, Ilovda DA, Yoshino A, Becker DP (1992) Administration of excitatory amino acid via microdialysis attenuates the increase in glucose utilization seen following concussive brain injury. J Cereb Blood Flow Metab 12:12-24.

Kemp JA, Foster AC, Leeson PD, Priestly T, Trigett R, Iverson LL, Woodruff GN (1988) 7-Chlorokynurenic acid is a selective antagonist at the glycine modulatory site of the $N$-methyl-D-aspartate receptor complex. Proc Natl Acad Sci USA 85:6547-6550.

Kessler M, Baudry M, Lynch G (1989) Quinoxaline derivatives are high affinity antagonists of the NMDA receptor-associated glycine sites. Brain Res 489:377-382.

Kleckner NW, Dingledine R (1988) Requirement for glycine in activation of NMDA receptors expressed in Xenopus oocytes. Science $241: 835-837$.

Kotapka MJ, Gennarelli TA, Graham DI, Adams JH, Thibault LE,
Ross DT, Ford I (1991) Selective vulnerability of hippocampal neurons in acceleration-induced experimental head injury. J Neurotrauma 8:247-258

Levin HS (1985) Outcome after head injury. Pt II. Neurobehavioral recovery. In: Status report on central nervous system trauma research, pp 281-299. Bethesda, MD: NINCDS.

Lowenstein DH, Thomas MJ, Smith DH, McIntosh TK (1992) Selective vulnerability of dentate hilar interneurons following traumatic brain injury. J Neurosci 12:4846-4853.

Lyeth BG, Jenkins LW, Hamm RJ, Dixon CE, Phillips LL, Clifton GL, Young HF, Hayes RL (1990) Prolonged memory impairment following traumatic brain injury in the rat. Brain Res 26:249-258.

MacDermott AB, Mayer ML, Westbrook SJ, Barker JL (1986) NMDA receptor activation increases cytoplasmic calcium concentration in spinal cord neurons. Nature 321:519-522.

McDonalds JW, Penny JB, Johnston MV, Young AB (1990) Characterization and regional distribution of strychnine-insensitive $\left[{ }^{3} \mathrm{H}\right]$ glycine binding sites in rat brain by quantitative receptor autoradiography. Neuroscience 35:653-668.

McIntosh TK, Noble L, Andrews B, Faden AI (1987) Traumatic brain injury in the rat: characterization of a midline fluid-percussion model. CNS Trauma 4:119-134.

McIntosh TK, Vink R, Soares H, Hayes R, Simon R (1989a) Effects of the $N$-methyl-D-aspartate receptor blocker MK-801 on neurologic function after experimental brain injury. J Neurotrauma 6:247-259.

McIntosh TK, Vink R, Noble LJ, Andrews B, Faden AI (1989b) Traumatic brain injury in the rat: characterization of a lateral fluid-percussion model. Neuroscience 28:233-244.

McIntosh TK, Vink R, Soares H, Hayes R, Simon R (1990) Effect of noncompetitive blockade of $N$-methyl-D-aspartate receptors on the neurochemical sequelae of experimental brain injury. J Neurochem 55:1170-1179.

Miller LP, Lyeth BG, Jenkins LW, Oleniak L, Hamm RJ, Phillips LL, Clifton GL, Hayes RL (1990) Excitatory amino acid subtype binding following traumatic brain injury. Brain Res 526:103-107.

Miyzaki S, Newlon P, Goldberg S, Jenkins L, Lyeth B, Katayama Y, Hayes $R$ (1989) Cerebral concussion suppresses hippocampal longterm potentiation (ITP) in rats. In: Intracranial pressure VII (Marmarou A, Hoff J, eds), pp 651-653. New York: Springer.

Monaghan DT, Cotman CW (1986) Identification and properties of $N$-methyl-D-aspartate receptors in rat brain plasma membranes. Proc Natl Acad Sci USA 83:7532-7536.

Monahan JB, Handelmann GE, Hood WF, Cordi AA (1989) D-Cycloserine, a positive modulator of the $N$-methyl-D-aspartate receptor enhances performance of learning tasks in rats. Pharmacol Biochem Behav 34:649-653.

Morris RGM (1989) Synaptic plasticity and learning: selective impairment of learning in rats and blockade of long-term potentiation in vivo by the NMDA receptor antagonist AP5. J Neurosci 9:30403057.

Morris RGM, Garrud P, Rawlins JNP, O'Keefe J (1982) Place navigation impaired in rats with hippocampal lesions. Nature 297:681683.

Morris RGM (1984) Developments of a water maze procedure for studying spatial learning in the rat. J Neurosci Methods 11:47-60.

Nilsson P, Hillered L, Ponten U, Ungerstedt U (1990) Changes in cortical extracellular levels of energy-related metabolites and amino acids following concussive brain injury in rats. J Cereb Blood Flow Metab 10:631-637.

Olton DS, Walker J A, Gage FH (1978) Hippocampal connections and spatial discrimination. Brain Res 139:295-308

Okiyama K, Smith DH, Thomas MJ, McIntosh TK (1992) Evaluation of a novel calcium channel blocker $(S)$-emopamil on regional cerebral edema and neurobehavioral function after experimental brain injury. J Neurosurg 77:607-615.

Parkin AL (1984) Amnesic syndrome: a lesion specific disorder? Cortex 20:479-580.

Priestley T, Horne AL, McKernan RM, Kemp JA (1990) The effect of NMDA receptor glycine site antagonists on hypoxia-induced neurodegeneration of rat cortical cell cultures. Brain Res 53:183-188.

Pulsinelli WA, Brierly JB, Plum F (1982) Temporal profile of neuronal damage in a model of transient forebrain ischemia. Ann Neurol 11: 491-498.

Reynolds IJ, Murphy SN, Miller RJ (1987) MK801 binding to the 
excitatory amino acid receptors from rat brain is enhanced by glycine. Proc Natl Acad Sci USA 84:7744-7748.

Reynolds IJ, Miller RJ (1988) Multiple sites for the regulation of the $N$-methyl-D-aspartate receptor. Mol Pharmacol 33:581-584.

Reynolds M, McCauley L, Sullivan B, Wrathall J (1989) Effects of antagonists of excitatory amino acids on functional deficits after contusive spinal cord injury. Soc Neurosci Abstr 15:130.

Rothman SM, Olney JW (1986) Glutamate and the pathophysiology of hypoxic-ischemic brain damage. Ann Neurol 19:105-111.

Scoville WB, Milner B (1957) Loss of memory after bilateral hippocampal lesions. J Neurol Neurosurg Psychiatry 20:11-21.

Shalaby I, Chenard B, Prochniak M (1989) Glycine reverses 7-C kynurenate blockade of glutamate neurotoxicity in cell culture. Eur J Pharmacol 196:309-311.

Shapira Y, Yadid G, Cotev A, Shomani E (1991) Protective effect of MK801 in experimental brain injury. J Neurotrauma 7:131-139.

Sheardown MJ, Neilsen EO, Hansen AJ, Jacobsen P, Honoré T (1990) 2,3-Dihydroxy-6-nitro-7-sulfamoyl-benzo(F)quinoxaline (NBQX) in a rat focal ischemia model. Science 247:571-574.

Smith DH, Okiyama K, Thomas MJ, Claussen B, McIntosh TK (1991) Evaluation of memory dysfunction following experimental brain injury using the Morris water maze. J Neurotrauma 8:259-269.

Smith DH, Lowenstein DH, Hicks RR, Perlman KG, McIntosh TK (1992) Experimental brain injury induces long-term memory dysfunction associated with bilateral hilar neuronal loss. Soc Neurosci Abstr 18:170.

Soares HD, Thomas MJ, Cloherty K, McIntosh TK (1992) Development of prolonged focal cerebral edema and regional cation changes following experimental brain injury in the rat. J Neurochem 58:18451852.
Somjen GG, Giacchino JL (1985) Potassium and calcium concentrations in interstitial fluid of hippocampal formation during paroxysmal responses. J Neurophysiol 53:1098-1 108.

Thomas MJ, Breault D, Nolan B, Smith DH, McIntosh TK (1990) The effects of experimental brain injury on regional cation concentrations. Soc Neurosci Abstr 16:777.

Vink R, McIntosh TK, Demediuk P, Weiner M, Faden A (1988) Decline in intracellular free $\mathrm{Mg}^{++}$is associated with irreversible tissue injury after brain trauma. J Biol Chem 263:757-761.

Yamakami I, McIntosh TK (1989) Effects of traumatic brain injury on regional cerebral blood flow as measured with radiolabeled microspheres. J Cereb Blood Flow Metab 9:117-124.

Yamakami I, McIntosh TK (1991) Alterations in regional cerebral blood flow following brain injury in the rat. J Cereb Blood Flow Metab 11:655-660.

Yeh G-C, Bonhaus DW, McNamara JO (1990) Evidence that zinc inhibits NMDA receptor gated ion channel activation by noncompetitive antagonism of glycine binding. Mol Pharmacol 38:14-19.

Young W, DeCrescito V, Flamm ES (1986) Tissue $\mathrm{Na}, \mathrm{K}, \mathrm{Ca}$ changes in regional cerebral ischemia: their measurement and interpretation. CNS Trauma 3:215-234.

Young W, Koreh I (1986) Potassium and calcium changes in injured spinal cords. Brain Res 365:42-53.

Yuan XQ, Prough DS, Smith TL, DeWitt DS (1989) The effects of traumatic brain injury on regional blood flow in rats. J Neurotrauma 5:289-301.

Zola-Morgan SM, Squire LR, Amaral DC (1986) Human amnesia and the medial temporal region: enduring memory impairment following bilateral lesions limited to the CA-1 field of the hippocampus. J Neurosci 6:2950-2967 